\title{
A cascaded H-bridge multilevel inverter with photovoltaic MPPT control
}

\author{
Khadija Ezzouitine ${ }^{1}$, Abdelkader Boulezhar ${ }^{1}$, \\ Youssef EL afou ${ }^{3}$ \\ ${ }^{1}$ Laboratory of renewable energy and dynamic of systems University Hassan II, Faculty of Sciences Ain-Chock Casablanca, Morocco \\ ${ }^{3}$ Physic Departement, faculty of Sciences Moulay Ismail, Meknes, Morocco and INRIA Non-A-groupe, University of Sciences \\ and Technology of Lille 1, LAGIS Laboratory, France
}

Article Info

Received Aug 19, 2018

Keyword:

$\mathrm{P} \& \mathrm{O}$

MPPT

Photovoltaic

MultilevelInverter

CHMLI.

\section{Corresponding Author:}

Khadija Ezzouitine

Laboratory of renewable energy and dynamic of systems University Hassan II, Faculty of Sciences Ain-

Chock Casablanca, Morocco

Email: Khadija.ezzouitine@gmail.com

\section{Introduction}

Photovoltaic energy is an important source of the renewable energy, it is an inexhaustible energy since it is derived from the sun's rays and, as such, it respects nature and the environment. It is a very reliable energy because there is no risk of rupture. In addition, the integration of photovoltaic panels in your home is simple and the installation is easy to use[1].

The cost of operation is low and maintenance is reduced. Nevertheless, photovoltaic energy is one of the major sources of renewable energy, it is an inexhaustible energy since it is derived from the sun's rays and, as such, it respects nature and the environment [3]. It is a very reliable energy because there is no c risk of rupture.

In addition, the integration of photovoltaic panels in your home is simple and the installation is easy to use. The cost of operation is low and maintenance is reduced. However, the production of this is nonlinear and it varies according to the luminous intensity and the temperature.

Therefore, the photovoltaic panel operating point (PV) does not always coincide with power maximum point then uses a mechanism that allows search and track of power point maximum called "Maximum power point tracking" (MPPT) so that the maximum power is generated continuously.

As a result, several studies have focused on photovoltaic systems. They have tried to develop algorithms to extract the maximum energy converted by the panel and then that allows optimal operation of the photovoltaic system [1].The PV module is essentially standard PV panel and DC-DC converter with MPPT Controller the 
modular power electronics technology named multilevel inverter.There are three topologies commonly used at multiple levels of theinverter such as diode inverter, capacitor inverter flyer and multilevel inverter cascade.

Among the above cascaded topologies, H-bridge topology is the most suitable for the integration of renewable energy.It is usedseparately Source DC can be powered from the PV panel[5] [6]. H-bridge in cascade the multilevel inverter is better than the other two types of multilevel inverter because of this require less component, the cascade topology allows the use of DC source with different voltage values, same input voltage the output voltage obtained with $\mathrm{H}$-bridge in cascade the multilevel inverter is twice as much as the output voltage with diode capacitor and flywheel capacitor and bridge power $\mathrm{H}$ cell connected in series to produce a high $\mathrm{AC}$ voltage.

A five-level modular H-bridge inverter cascade topology for the photovoltaic system connected to the threephase network is presented in this document. The P \& $\mathrm{O}$ algorithm extracts maximum power from the panels while the monitoring system tends to control the DC levels in the CHMLI inputs [5].

\section{Photovoltaic power system}

\subsection{Photovoltaic cell model}

A photovoltaic cell is a component made of semiconductor material that absorbs light energy and transforms it into electrical current. The operating principle uses the properties of light radiation absorption by semiconductor materials. To construct PV cells scientists relate to the physical proprieties of electrons subject to release from their original atoms when excited by photons in the solar radiation. The movement of these electrons forms a DC current which creates a DC voltage at the PV cell terminals. This phenomenon is called photovoltaic effect; Figurel presents a photovoltaic cell [1].

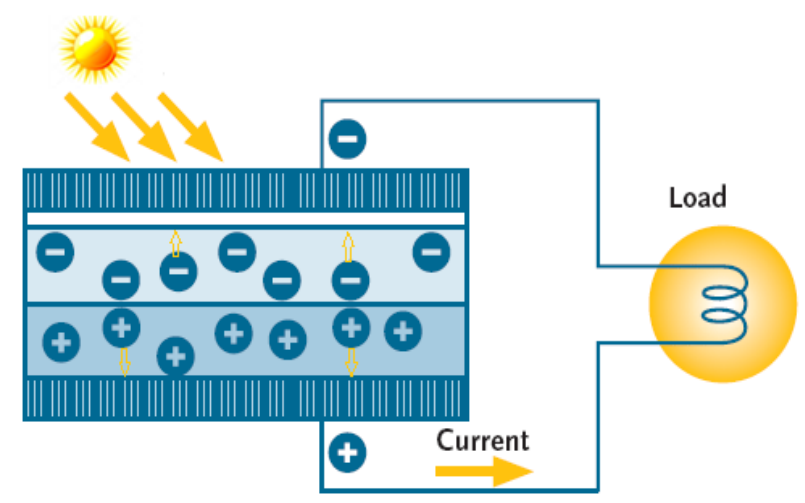

Figure 1. Presentation of a Photovoltaic Cell

In order to study a PV cell, many mathematical models may be used. Hereafter we study two equivalent models.

\subsection{Double diode PV Cell model}

In a double diode PV cell model two diodes D1 and D2 having respectively the saturation currents I1 and I2 are connected in parallel. The current source representing the PV Cell depends on sun's irradiation and produces a current ICC . The series resistance RS is an actual representation of the resistivity of the material and the semi-conductor-metal contact. The parallel resistance RP on the other is a supplement shunt resistance. Figure2 presents a two diodes model of a PV Cell.

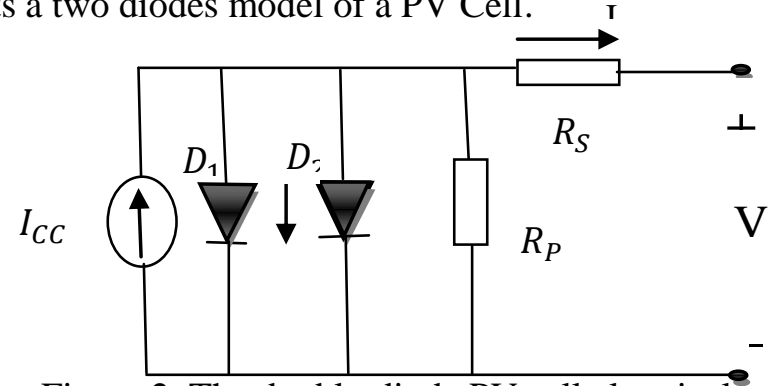

Figure 2. The double-diode PV cell electrical model 
The current supplied by the PV Cell can be written as follows (Helali, 2012):

$$
I=I_{c c}-I_{1}\left[e^{q\left(\frac{V+I R_{S}}{n_{1} K T}\right)}-1\right]-I_{2}\left[e^{q\left(\frac{V+I R_{S}}{n_{2} K T}\right)}-1\right]-\frac{V+I R_{S}}{R_{P}}
$$

Different Parameters

- I1, I2 The diodes reverse current saturation D1 and D2

- $\mathrm{K}(1.381 \times 10-23 \mathrm{~J} / \mathrm{K})$, the Boltzmann constant,

- $\mathrm{T}(\mathrm{K})$, the effective temperature of the cell,

- $\mathrm{q}(1.602 \times 10-19 \mathrm{C})$, the charge of electron,

- $\mathrm{n} 1, \mathrm{n} 2$ The ideality factors

- I (A), the PV cell output Current,

- $\mathrm{V}(\mathrm{V})$, the module thermal voltage,

- $\operatorname{RP}(\Omega)$, the shunt resistor,

- $\operatorname{RS}(\Omega)$, the series resistance.

\subsection{Single diode PV Cell model}

The model Single diode is simple, it has a current source parallel to the diode. The accretion of the model that introduces a supplementary resistance shunt Rp exhibited in Figure3.

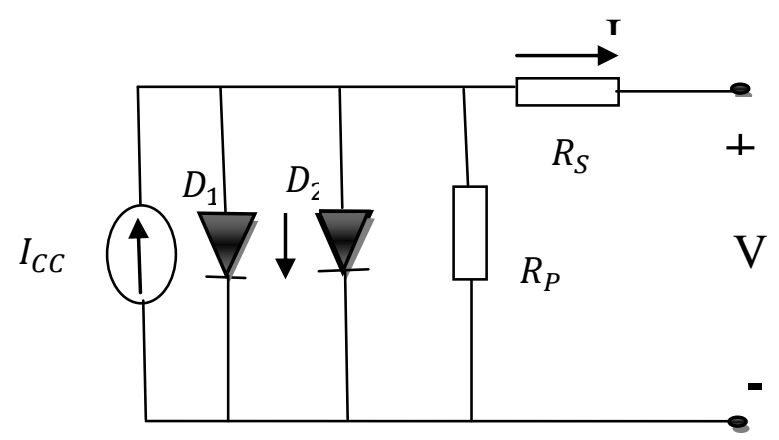

Figure 3. A-diode PV cell electrical model

The current supplied by the PV Cell can be written as follows (Pétion, 2009), (Cabal, 2008), (Cid Pastor, 2006) and (Helali, 2012):

$$
I=I_{c c}-I_{1}\left[e^{q\left(\frac{V+I R_{S}}{n_{1} K T}\right)}-1\right]-\frac{V+I R_{S}}{R_{P}}
$$

\subsection{Characteristic of the PV Cell}

To analyze the both PV model behavior, a simulation is made in MATLAB To have a comparaison of PV models and to show the effect of different parameters. The specifications are quoted in Table 1 and2. 
Table 1.The Cell module electrical characteristics data.

\begin{tabular}{|l|l|}
\hline TypicalElectrical Performance & \multicolumn{1}{|l}{} \\
\hline Open Circuit Voltage & $0.665 \mathrm{~V}$ \\
\hline Short Circuit Current & $5.75 \mathrm{~A}$ \\
\hline Maximum Power Voltage & $0.560 \mathrm{~V}$ \\
\hline Maximum Power Current & $5.35 \mathrm{~A}$ \\
\hline Rated Power & $3.0 \mathrm{~W}$ \\
\hline Efficiency & $20.0 \%$ minimum \\
\hline Temperature Coefficients Voltage & $-1.9 \mathrm{mV} /{ }^{\circ} \mathrm{C}$ \\
\hline Temperature Coefficients Power & $-0.38 \% /{ }^{\circ} \mathrm{C}$ \\
\hline
\end{tabular}

Table 2:Electrical characteristics data of panel module.

\begin{tabular}{|c|c|}
\hline \multicolumn{2}{|c|}{$\begin{array}{l}\text { Electrical Characteristics } \\
\text { Measured under standard test conditions: } 1000 \mathrm{~W} / \mathrm{m}^{2} \text { of sunlight, } \mathrm{AM} 1.5 \text { and } 25^{\circ} \mathrm{C} \text { cell temperature }\end{array}$} \\
\hline Rated power $(+5 \% /-3 \%) \mathrm{P}$ & $300 \mathrm{~W}$ \\
\hline Voltage at maximum power Vpm & $54,7 \mathrm{~V}$ \\
\hline Current at maximum power Ipm & $5,49 \mathrm{~A}$ \\
\hline Open circuit voltage VCO & $64,0 \mathrm{~V}$ \\
\hline Short circuit currentIcc & $5,87 \mathrm{~A}$ \\
\hline Maximum voltage of system IEC & $1000 \mathrm{~V}$ \\
\hline Temperature Coefficients Power & $-0,38 \% / \mathrm{K}$ \\
\hline Temperature Coefficients Voltage (Vco) & $-176,6 \mathrm{mV} / \mathrm{K}$ \\
\hline Temperature Coefficients Current (Icc) & $3,5 \mathrm{~mA} / \mathrm{K}$ \\
\hline NOCT & $45^{\circ} \mathrm{C}+/-2^{\circ} \mathrm{C}$ \\
\hline Nominal value of standard fuses & $15 \mathrm{~A}$ \\
\hline $\begin{array}{l}\text { Rolling currentlimit } \\
\text { (3 strings / rows) IR }\end{array}$ & $14,7 \mathrm{~A}$ \\
\hline
\end{tabular}

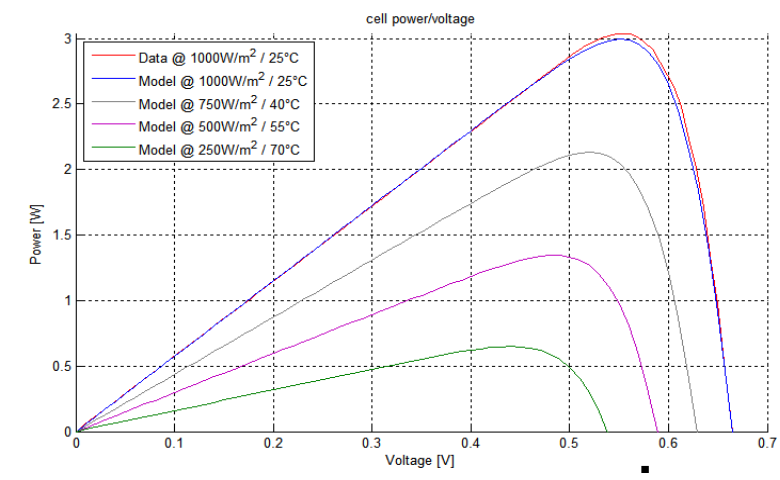

Figure 4. The model of Matlab I-V curves of different irradiation levels. 


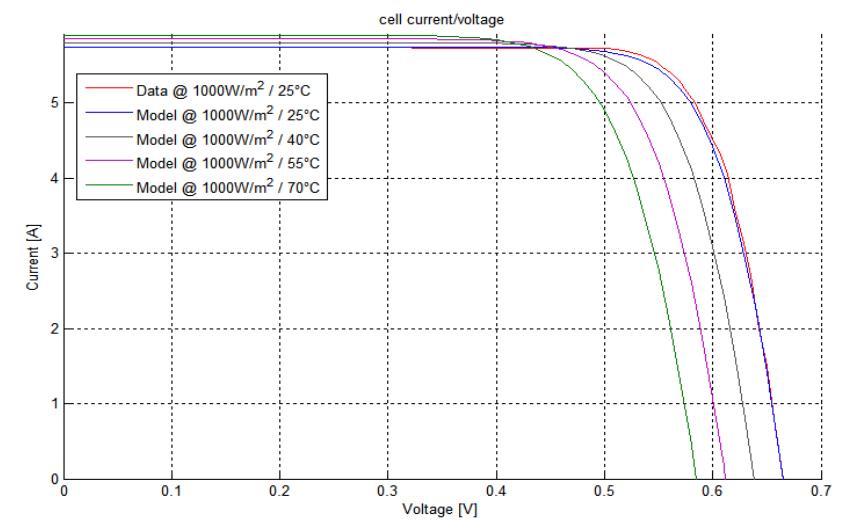

FIGURE 5. The model of Matlab I-V curves of different temperatures levels.

\section{Maximum power point tracker}

Maximum power point tracing (MPPT) The Power point tracker is a high frequency DC to DC converter .They took the input DC from the solar panels change it to high frequency $\mathrm{AC}$, and convert it back down to a different DC voltage and current to exactly correspond t panels at batteries.

Therange of 20-80 kHz is usually assigned to the work of MPPT . The large frequency circuits advantagesis their abilityto be designed with a large efficiency transformers and small components[1] [4].

Many methods of finding the MPP hade been published. These techniques are different in various aspects like as complexity ,cost,convergence speed,required sensors, tracking while irradiation change of temperature, effectiveness range, correct, needed hardware at thepopularity or implementation, among others. A review completed of 19 algorithms MPPT is found at[7].

The algorithms InCond and $\mathrm{P} \& \mathrm{O}$ are the most frequent.

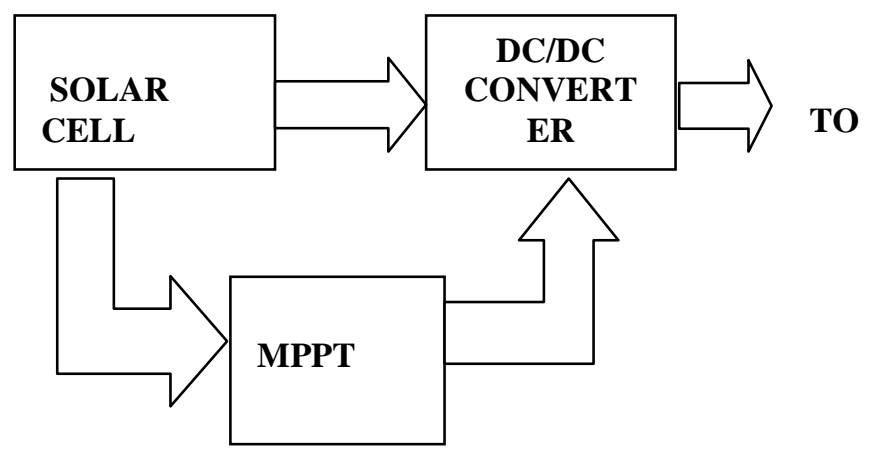

Figure 6.Block diagram of Typical MPPT system.

\subsection{P\&O algorithm for MPPT control}

In renewable energy, optimization algorithms of the MPPT problem are used to increase energy transformation. Among the much used algorithms, we have the $\mathrm{P} \& \mathrm{O}$, used by many authors. Its few code lines and simplicity make it easy to deploy[9].

The disadvantage of this algorithm is that in some cases, especially under partial shading, the algorithm cannot find the maximum power point. As it is a widely used algorithm, it is a good idea to implement it and take it as a reference point. 


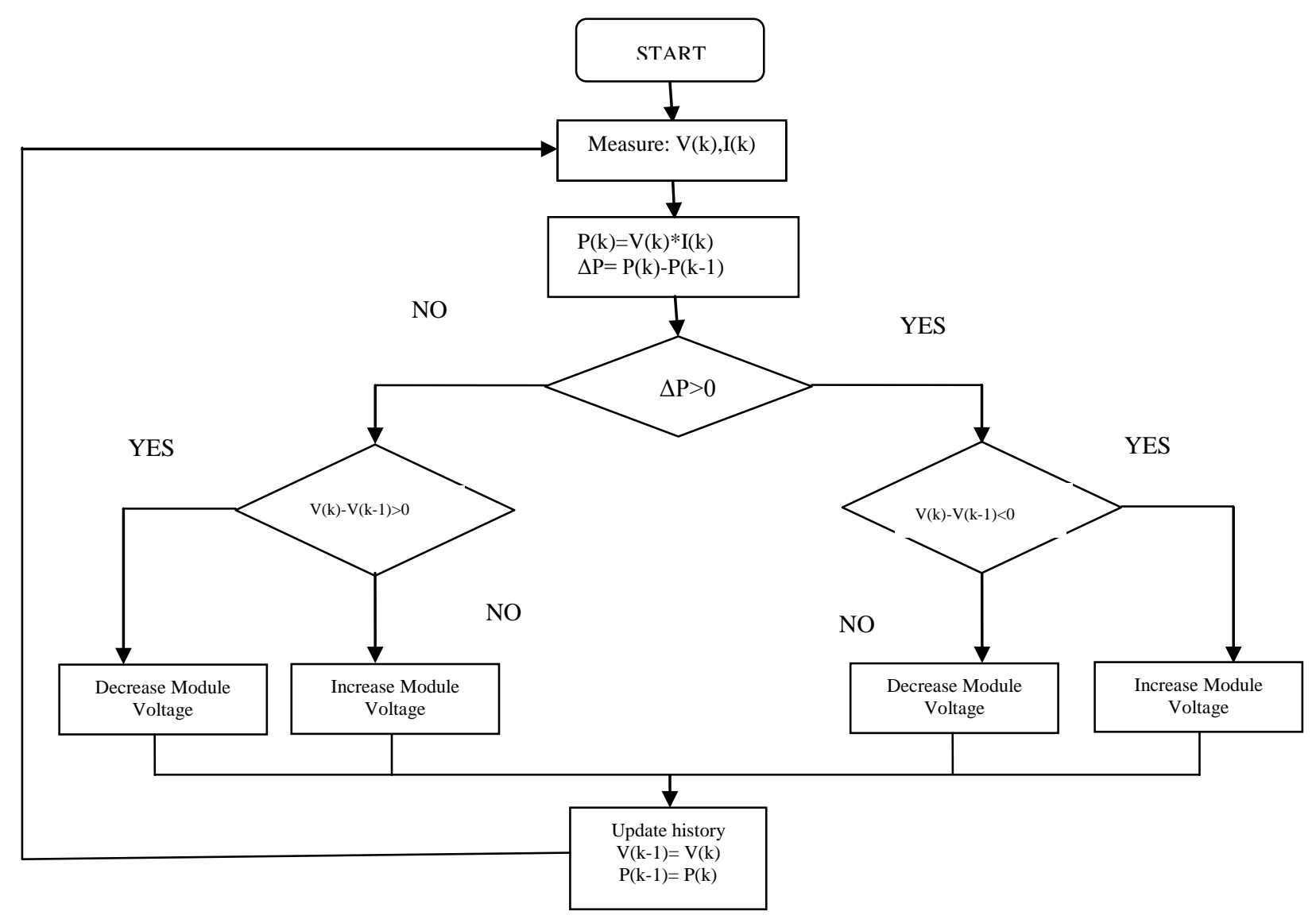

Figure 7. the $\mathrm{P} \& \mathrm{O}$ algorithm Flowchart .

\subsection{Simulation of the $P V$ system for variation of temperature or irradiance}

The photovoltaic system studied is composed of the PV panel, the MPPT control based on P\&O algorithm, a DC-DC boost converter and a resistive load as shown in Figure 8.

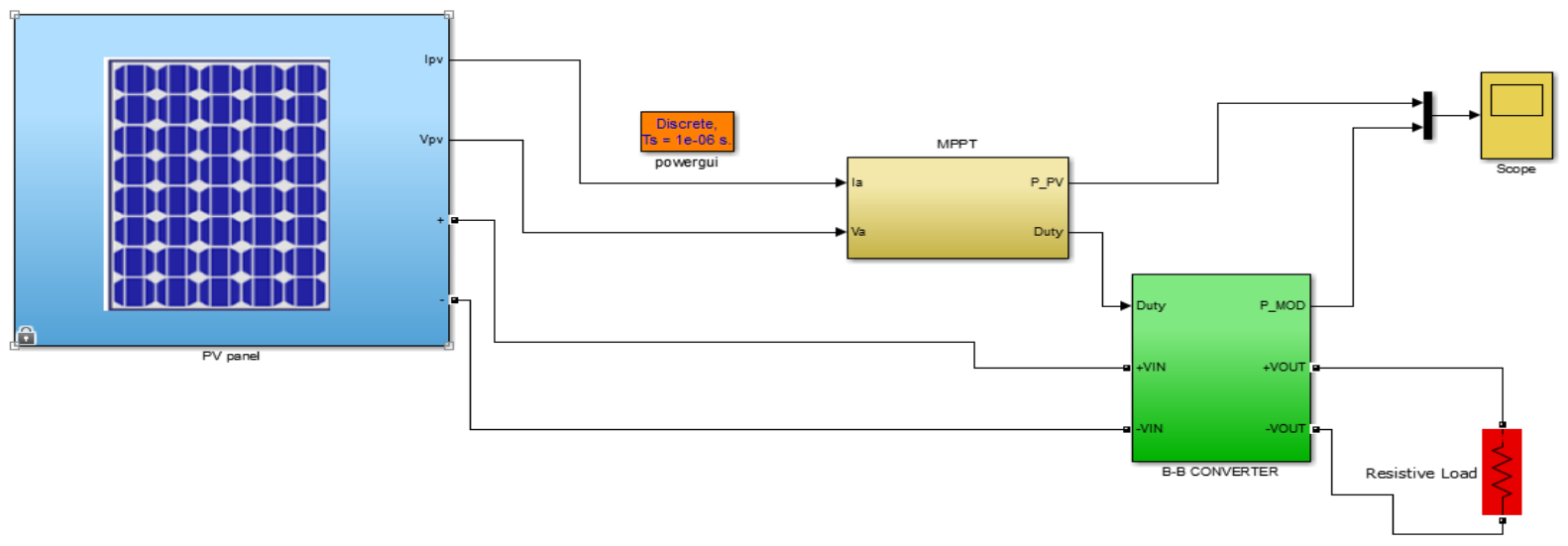

Figure 8.Photovoltaic system 
The simulation in matlab-simulink results are given by the following figure:

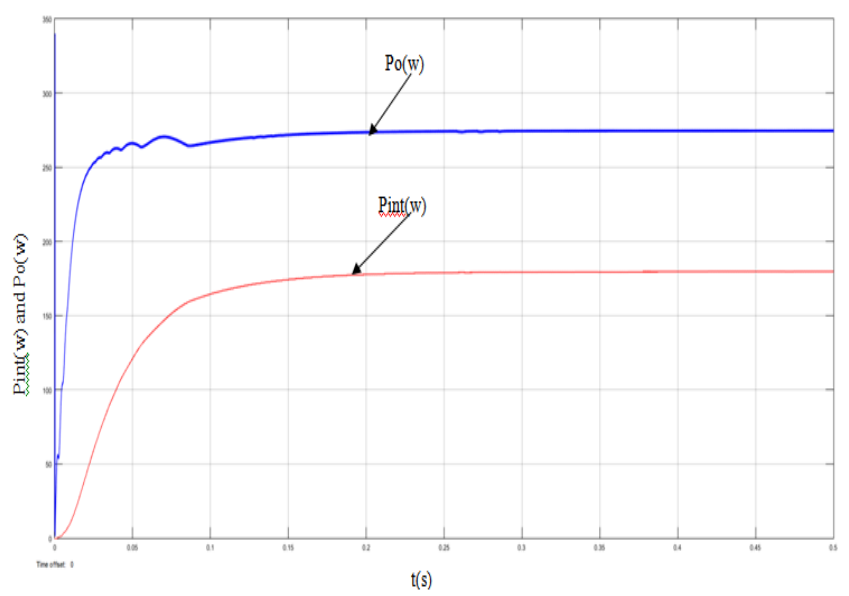

Figure 9.Pin $(\mathrm{t}) \& \operatorname{Po}(\mathrm{t})$.

\subsection{Analysis of the simulation results}

In this section, we carry out the simulation results for the both variation Pin(t) \& Po(t). La figure 9 shows the power with and without MPPT regulator while this technology offers an appreciable power gain of the order of $20 \%$ to $30 \%$.

\section{DC/AC multilevel conversion}

\subsection{Generalities about the multilevel inverter}

Two categories of multilevel inverter are currently listed. The first groups the main inverters into three groups: 1) Loop diode inverters (in English clamping diodes called diode clamp) Neutral Point Clamped (NPC) and Multiple Point Clamped (MPC)[8].

2) Float capacitor inverter [or Flying Capacitor (FC)]

3) H-bridge cascade bridge inverter.

The second category of multilevel inverters includes the hybrid assemblies of inverters of the first category [5]. Thus, among others we can mention:

1) NPC in cascade (CDC),

2) H-bridge in cascades $(\mathrm{CMH})$,

3) NPC and H-bridge cascading $(\mathrm{CDCH})$

\subsection{H-Bridge Multilevel Inverters}

The first inverter model was the bridge inverter $\mathrm{H}$ (H-bridge), which appeared in 1975.

Advancement of multilevel inverters was due to the series $\mathrm{H}$ cascaded bridge model. TheThe first $\mathrm{H}$ bridge inverter application was for plasma stabilization in 1988 [6]. The bridge inverters outputs are in series so that voltage wave synthesized is the output sum voltages. The major advantage of this approach is that the number of steps on the pattern of the voltage can be increased without any addition of new components. The use of serial power conversion cells allows increasing the number of voltage and power level of the converter. But the disadvantage major feature of this topology is the large number of isolated DC voltages required for each bridge [5]. 


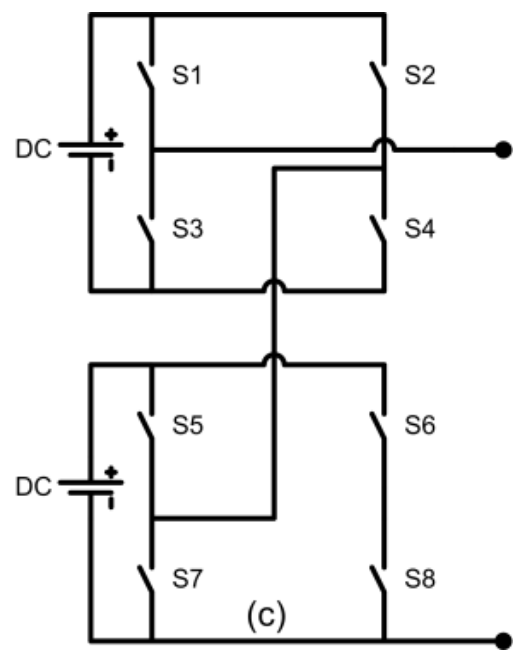

Figure 20. Inverter H-bridge 5 levels.

For an inverter with $\mathrm{k}$ levels, the number of elements constituting its topology: $\mathrm{s}$ for isolated DC sources, $\mathrm{m}$ for the power transistors are given, for each phase, by the following relationships:

$$
\begin{aligned}
& s=(k-1) / 2 \\
& m=2 *(k-1)
\end{aligned}
$$

However, the cells can be powered by phase shifted transformers medium voltage to provide higher power. In this case, if $n s$ is the number of independent sources, the number of levels of the output voltage $n n$ is given by the equation below:

$$
n n=2 n s+1
$$

\subsection{Simulation and analysis of the CHMLI model study}

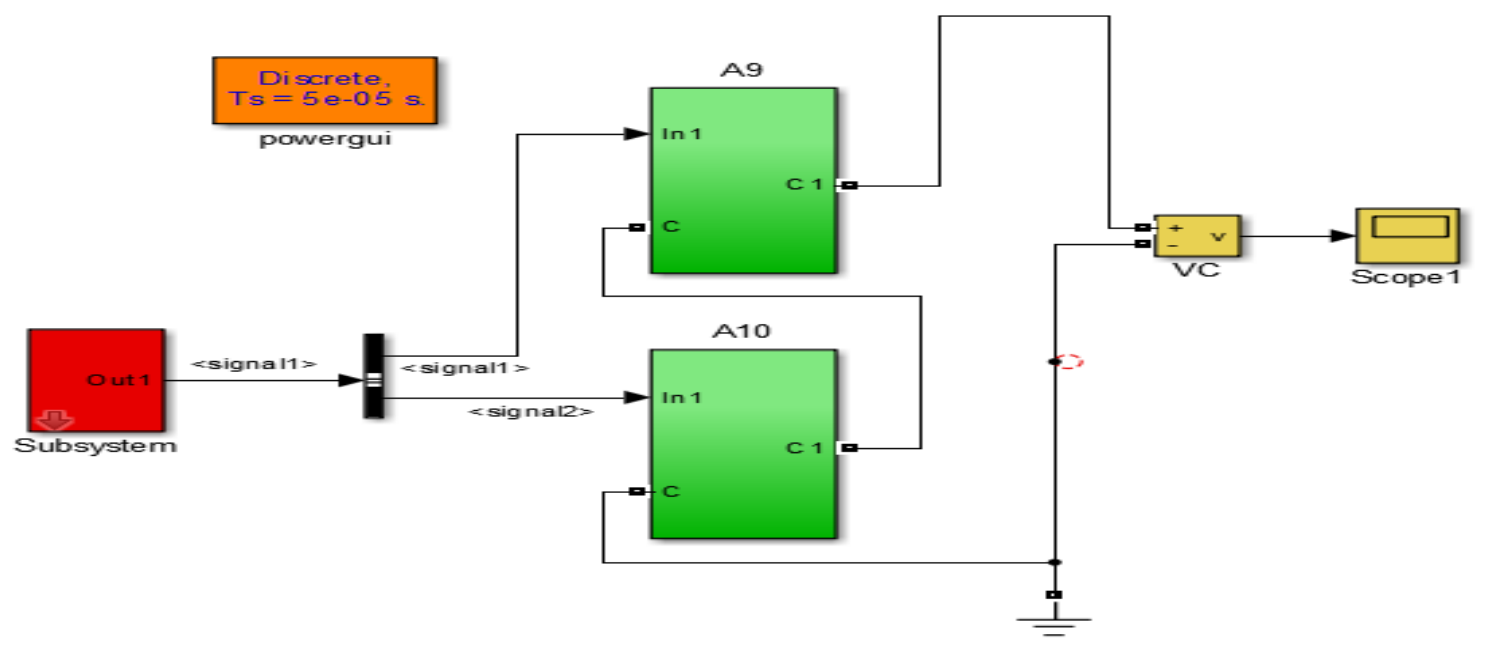

Figure 31. The multilevel inverter cascaded H-Bridge 


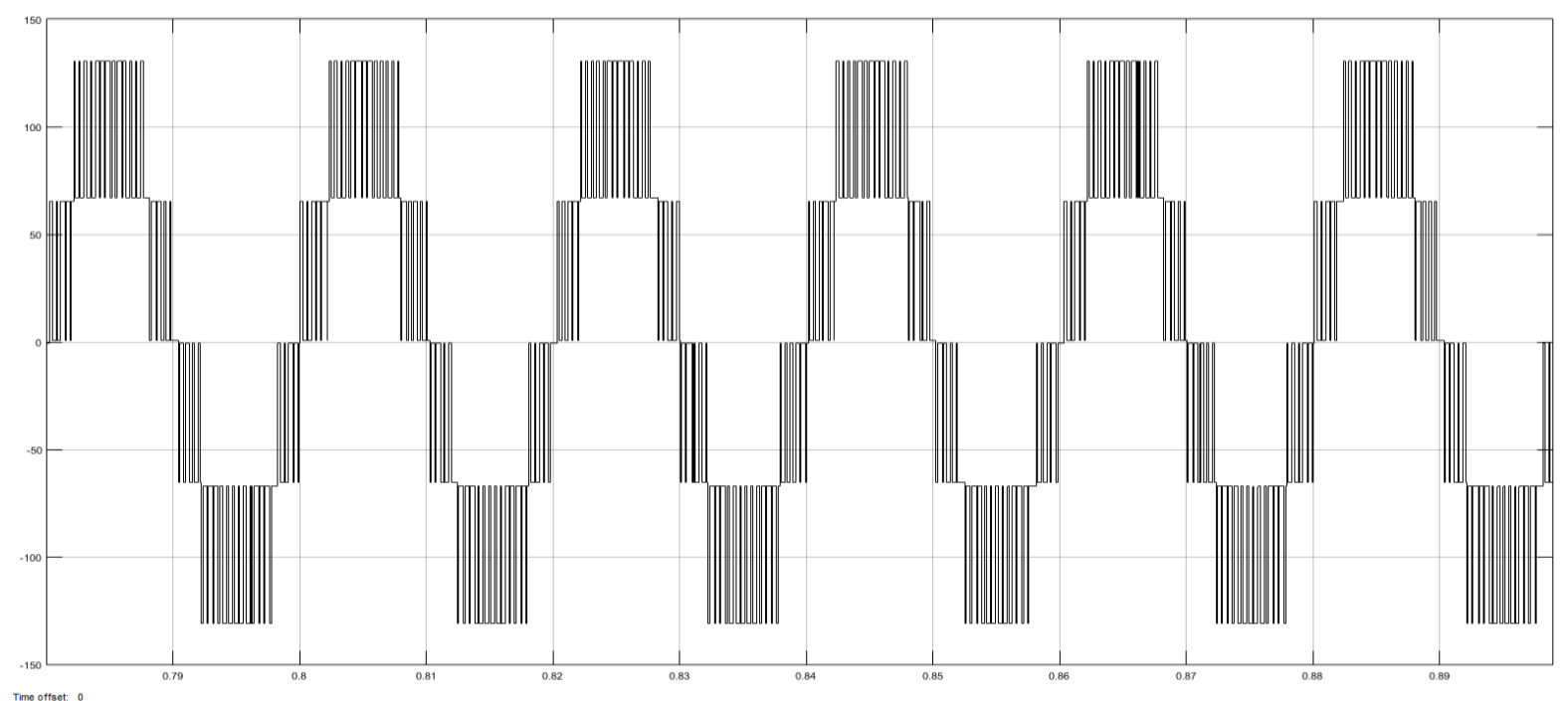

Figure 42. Voltage output of the 5 levels cascaded H-Bridge multilevel inverter.

This Figure gives the voltage output of CHMLI before each balancing procedure.

\section{Simulation and analysis of the PV generator with MPPT and CHMLI}

\subsection{Model of the PV with MPPT algorithm P\&O and CHMLI}

Multiple PVarrays connected in series before DC-DC converter by a single MPPT controller.

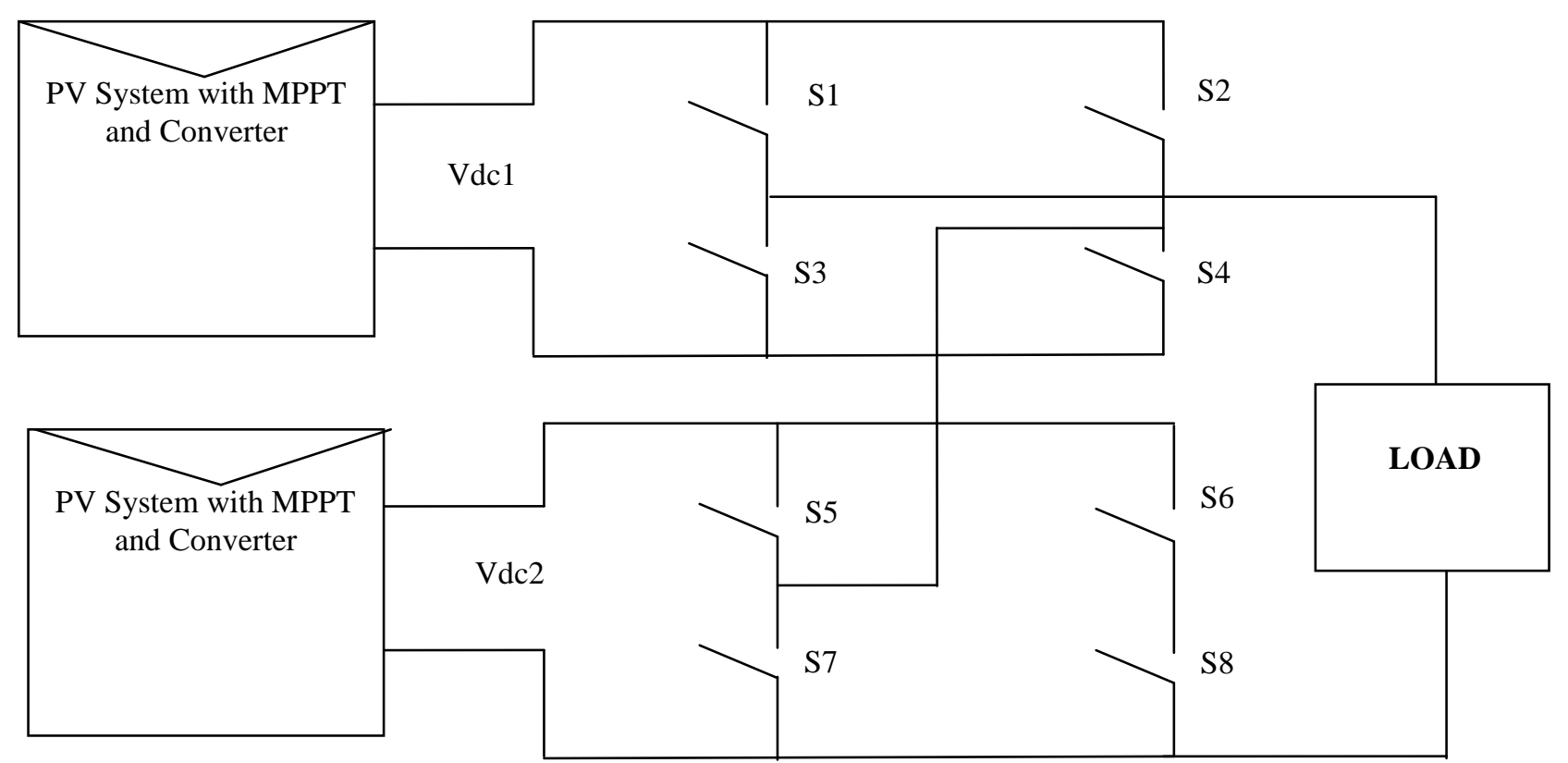

Figure 53. Integration PV System with MPPT and CHMLI 


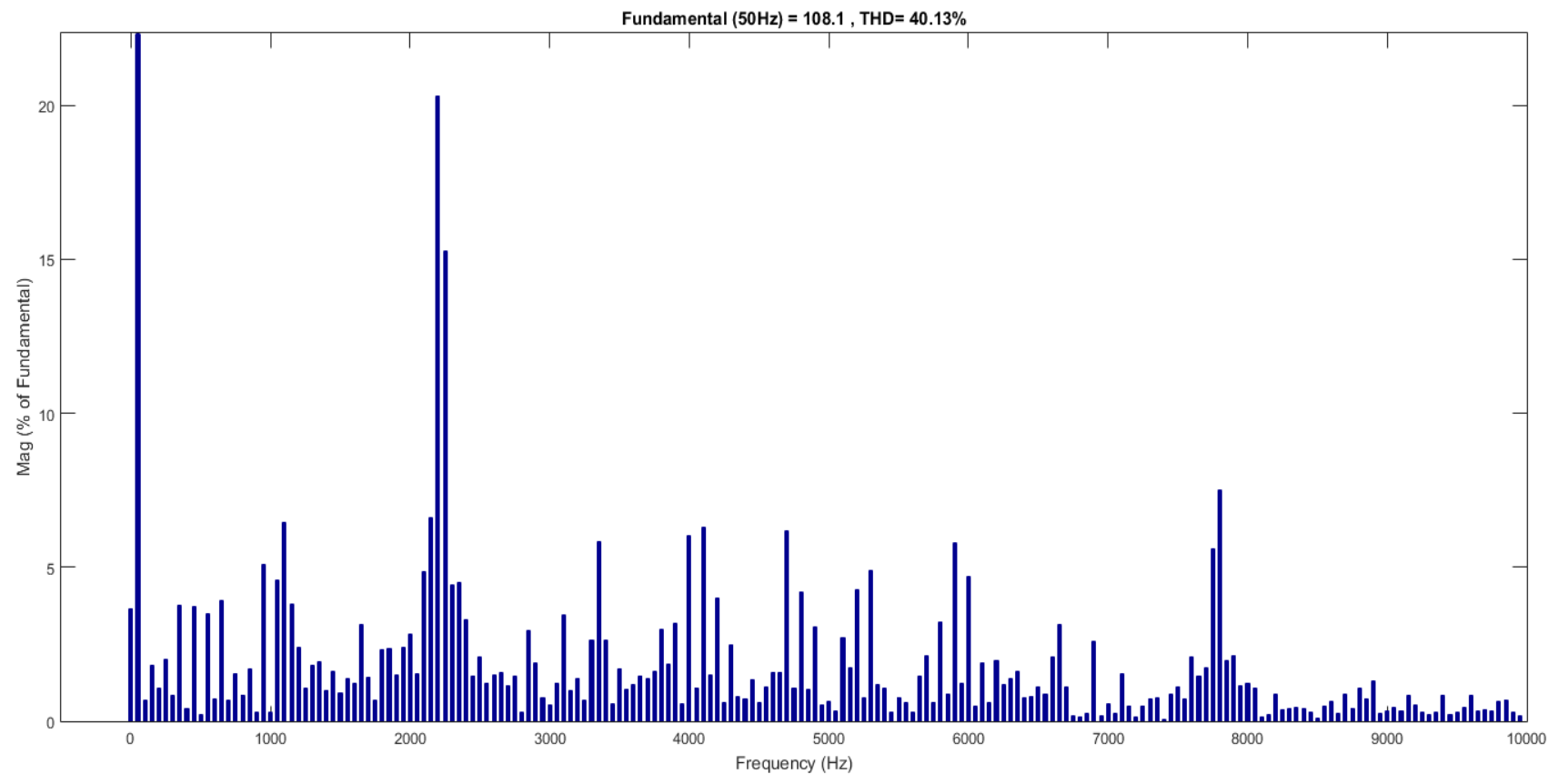

Figure 64. Output voltage spectrum analysis of the 5 levels CHMLI with MPPT

\subsection{Analysis of the simulation results}

The figure gives the spectrum voltage analysis; we recorded a $32.14 \%$ THD. We observe that before the use of the MPPT the CHMI multilevel inverter works randomly with the DC inputs provided by the PV which generates a low efficiency. While with the application of the MPPT to CHMLI, its last works at the best possible power point, this implies better performance and optimal operation using resistive loads.

\section{Conclusion}

In this work, we proposed the design and simulation of photovoltaic systems PV, MPPT and CHMLI. We have described the photovoltaic PV module, these characteristics and the simulation of the I-V curves of the model. We presented the role of the MPPT technique with the P \& O algorithm, thus the simulation in the Matlab-simulink environment of the MPPT and a multilevel H-Bridge inverter in cascade of five levels then make the simulation of the two montages. Finally we extracted the curves and we analyzed them.

In a second step, we integrated PV, MPPT and CHMI systems with a resistive load. The results of the simulation showed that the system operates at its maximum power in a satisfactory manner.

\section{Acknowledgements}

I warmly thank Mr. Abdelkader BOULEZHAR, Professor at the University Hassan II Casablanca, thesis supervisor, for ensuring pleasant follow-up of my work.

\section{References}

[1] H.L.Tsai,C.S. Tu, Y.J. Su , "Development of Generalized Photovoltaic Model Using matlab/simulink. WCECS", San Francisco USA,2008, 22 - 24.

[2] B. Xiao ,L. Hang, J. Mei, C.R. Leon, M..Tolbert, B.Ozpineci, "Modular cascaded H-bridge multilevel PV inverter with distributed MPPT for grid connected application" IEEE trans. Ind. application.vol.5, NO.2,pp.1722- 1731,2015.

[3] H. T. Duru "A maximum power tracking algorithm based on $\operatorname{Impp}=\mathrm{f}(\mathrm{Pmax})$ function for matching passive and active loads to a photovoltaic generator" Solar Energy 80, 2006,812-822. 
[4] N. Chandrasekaran and K. Thyagarajah , "Modeling and MATLAB Simulation of Pumping System using PMDC Motor Powered by Solar System". European Journal of Scientific Research Vol.59 No.1, ISSN 1450-216X, pp. 6-13, 2011.

[5] Khalili, A. Bouattan ,T. Raihani , O. Ouajji, H. Amri, “ analysis study of a cascaded h-bridge multi-level inverter dedicated to power bank usage". Journal of Theoretical and Applied Information Technology,,88(3),434,2016.

[6] Sahoo, S. K., Bhattacharya, “ T.Phase-Shifted Carrier-Based Synchronized Sinusoidal PWM Techniques for a Cascaded H-Bridge Multilevel Inverter". Transactions Power Electronics IEEE 33(1), pp.513524,2018 .

[7] Gow, A. and Manning, C.D. " Development of a Photovoltaic Array Model for Use in Power-Electronics Simulation Studies". IEE Proceedings-Electric Power Applications,pp.146, 193-200,1999.

[8] A.P.K Yadav, S .Thirumaliah, G.Haritha . "Comparison of MPPT Algorithms for DC - DC Converters Based PV Systems". International Journal of Advanced Research, pp.18-23, 2012.

[9] E. Kandemir. S.Numan . Cetin. S. Borekci . "A Comparison of Perturb \& Observe and Fuzzy-Logic Based MPPT Methods for Uniform Environment Conditions”. PEN Journal,pp. 2303-4521,2017.

[10] United Nations Industrial Development Organization, "UNIDO and Renewable Energy; Greening the Industrial Agenda" Vienna, 2009.

[11] A. Lopez, B. Roberts, D. heimiller, N. Blair, G. Porro, U.S Renewable Energy.

Technical Potentials: A GIS-Based Analysis" Technical Report NREL/TP-6A20-5146, 2012

[12] United Nations Industrial Development Organizatio, 'UNIDO and Renewable Energy; Greening the Industrial Agenda' Vienna, 2009. 